Article

\title{
Soluble Inorganic Arsenic Species in Atmospheric Submicron Particles in Two Polish Urban Background Sites
}

\author{
Katarzyna Nocoń ${ }^{1, *}$, Wioletta Rogula-Kozłowska ${ }^{1}$, Grzegorz Majewski ${ }^{2}$ and \\ Patrycja Rogula-Kopiec ${ }^{1}$ \\ 1 Institute of Environmental Engineering, Polish Academy of Sciences in Zabrze, M. Skłodowskiej-Curie 34 \\ Str., 41-819 Zabrze, Poland; wioletta.rogula-kozlowska@ipis.zabrze.pl (W.R.-K.); \\ patrycja.rogula-kopiec@ipis.zabrze.pl (P.R.-K.) \\ 2 Institute of Environmental Engineering, Warsaw University of Life Sciences, Nowoursynowska 166, \\ 02-776 Warsaw, Poland; info@sggw.pl \\ * Correspondence: katarzyna.nocon@ipis.zabrze.pl
}

Received: 21 November 2019; Accepted: 17 January 2020; Published: 22 January 2020

\begin{abstract}
This paper presents results of the research on soluble inorganic $\mathrm{As}(\mathrm{III})$ and $\mathrm{As}(\mathrm{V})$ bound to submicron atmospheric particles (PM1) in two Polish urban background sites (Zabrze and Warsaw). The purpose of the research was to give some insight on the susceptibility to leaching of PM1-bound arsenic species from easily water-soluble compounds, i.e., considered potentially bioavailable based on its daily and seasonal changes. Quantitative analysis for 120 PM1 samples (collected from 24 June 2014 to 8 March 2015) was performed by using a high-performance liquid chromatography in combination with inductively coupled plasma mass spectrometry. The mean seasonal concentrations of dominant soluble As specie- $\mathrm{As}(\mathrm{V})$-ranged from $0.27 \mathrm{ng} / \mathrm{m}^{3}$ in the summer season in Warsaw to $2.41 \mathrm{ng} / \mathrm{m}^{3}$ in the winter season in Zabrze. Its mean mass shares in total As were $44 \%$ in Warsaw and $75 \%$ in Zabrze in the winter and $18 \%$ and $48 \%$, respectively, in the summer. Obtained results indicated fossil fuel combustion as the main source of PM1-bound $\mathrm{As}(\mathrm{V})$ and road traffic emission as its minor sources. In opposite to As(V), soluble As(III) was not clearly seasonally variable. In both seasons, its mean concentrations were higher in Zabrze than in Warsaw. As(III) concentrations were not preferentially shaped by an exact emission from road traffic in both cities.
\end{abstract}

Keywords: As(V); As(III); water-soluble arsenic; submicron particles; PM1; HPLC-ICP-MS

\section{Introduction}

The presence of fine particulate matter (PM), i.e., PM1 (particles with an aerodynamic diameter $\leq 1 \mu \mathrm{m}$ ) in the atmosphere is a major air quality problem in large urban agglomerations [1,2]. Submicron particles are an effective carrier for various metals and metalloids, including toxic elements such as arsenic (As). As and its compounds have been placed in group 1-that is to say, they have epidemiologically proven carcinogenic activity—by the International Agency for Research on Cancer (IARC) [3].

Atmospheric As is emitted primarily by anthropogenic sources (e.g., high-temperature industrial processes, fossil fuel combustion), reaching close to two-thirds of its total emissions [4]. These sources generate primarily fine particles with prevailing amounts of submicron ones [5]. So, As tends to accumulate in fine PM, especially in PM1 [1]. In Europe, the typical ambient concentration of As in urban areas is between 0.5 and $3 \mathrm{ng} / \mathrm{m}^{3}$, and is definitely higher-as high as $50 \mathrm{ng} / \mathrm{m}^{3}$ —in some industrial areas [6]. 
Although in big cities, pollution by PM and PM-bound As is related to the power and industry sectors, vehicular emissions have also become an important source. In Europe, the emission of As in the few tenths to few hundred $\mu \mathrm{g}$ per $\mathrm{kg}$ of burned diesel and petrol is reported [7]. Traffic road emissions have been shown to generate lower As concentrations compared to combustion emissions, e.g., As concentrations in PM1 of $0.69 \mathrm{ng} / \mathrm{m}^{3}$ and in PM2.5 of $0.75 \mathrm{ng} / \mathrm{m}^{3}$ were reported [8].

PM1 is an important factor in the spread of As in the environment and directly in living organisms after inhalation. As compounds that are the most mobile in the natural environment and bioavailable to living organisms, i.e., those that are easily soluble in water will pose the greatest potential threat. A wide range of concentrations of PM-bound water-soluble As have been reported [9-17]. Generally, it was found that As in fine PM binds mainly in water-soluble compounds [10,11]. The mass percentage of water-soluble As in total fine PM-bound As (industrial and municipal origin) ranged from a few percent to over 90\% [9-17].

However, evaluation of the potential toxicity of As is based on the distribution of its chemical forms $[16,17]$. Inorganic As species are considered more toxic than organic ones. Inorganic As compounds impair the metabolic processes of liver and kidney cells by inhibiting the enzymes that regulate them. It is also known that As compounds are characterized by varying toxicity and mobility in the environment, depending on the As oxidation state. As(III) is both more toxic and more mobile in the environment compared to $\mathrm{As}(\mathrm{V})$ [18]. As in PM exists as $\mathrm{As}(\mathrm{III})$ and $\mathrm{As}(\mathrm{V})$, in inorganic and/or organometalloid forms. Inorganic As species, in particular $\mathrm{As}(\mathrm{V})$, are the predominant species in atmospheric PM [19]. So, it is important to determine the ambient concentrations of the chemical forms of PM-bound As in addition to the total content of As in PM.

The availability of research concerning speciation analyses of As in PM still remains very limited [20]. Scarcely investigated in particular is PM1-bound As (especially its water-soluble compounds), although there is sufficient evidence that it is rich in toxic elements and can be responsible for negative health effects.

In Poland, almost all fine PM originates from anthropogenic emissions, mainly industrial, municipal, and road traffic emissions [21-23]. The shares of individual anthropogenic emission sources in the total emissions vary during the year (winter vs. summer season) in urban areas of Poland. Consequently, seasonal changes in the chemical composition of fine PM including its submicron fraction, can be seen [21]. Therefore, the quantity and chemical quality (species) of PM1-bound As can also be seasonally variable according to seasonal changes in PM emitted by local and regional sources.

The aim of the present study was to analyze the seasonal variability of soluble inorganic forms of PM1-bound As (As(III) and As(V)) in two Polish cities (Zabrze and Warsaw), differing in terms of topographic conditions, emission structure, and thermodynamic conditions of the atmosphere.

\section{Materials and Methods}

\subsection{Measurement Sites and Samples Collection}

Two locations for PM1 sampling were selected: one in the central part of Poland, in Warsaw, and the second in Southern Poland, in Zabrze (Figure 1). Both were selected as urban background locations [24] and were representative of an area of a few square kilometers. 

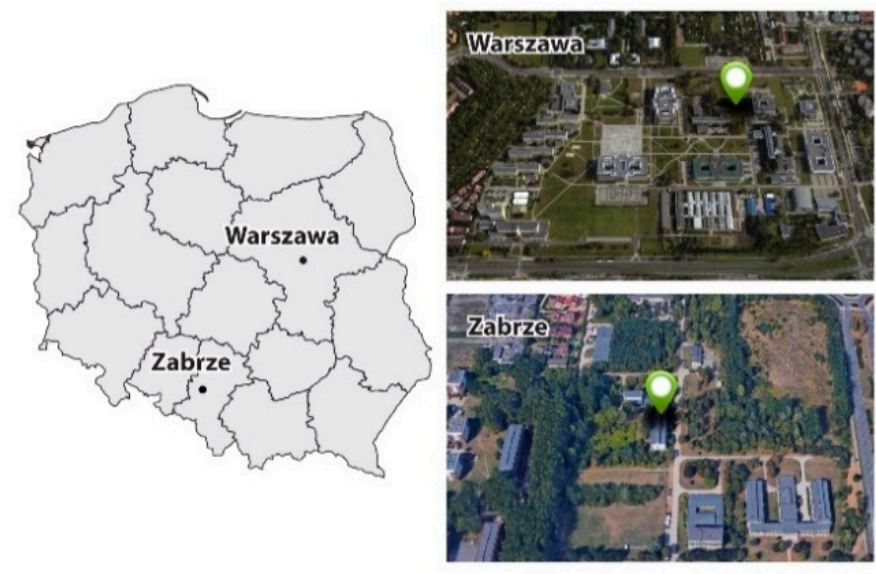

Figure 1. Location of the sampling points in Zabrze and Warsaw.

Zabrze, located in the most industrialized and urbanized region of Poland (Upper Silesia), is a densely built-up and populated city with a well-developed road transport network. Emission from energy production, industry, and road transport are the main sources of PM1 in the city. Warsaw, the largest agglomeration in the country, is characterized by a dense network of streets and roads with heavy traffic load, with the city center at the forefront. PM comes both from local sources, mainly the energy production sector and vehicular transport, and long-distance transport from heavily polluted Southern Poland [22].

Twenty four-hour PM1 samples were collected from 24 June to 24 August 2014 (61 samples in Zabrze and 60 samples in Warsaw) and from 8 January to 8 March 2015 (56 samples in Zabrze and 58 samples in Warsaw), simultaneously at both sites.

Two low-volume air samplers $\left(2.3 \mathrm{~m}^{3} / \mathrm{h}\right)$ equipped with a PM1 sampling head and quartz fiber filters were used for PM1 collection [22]. The filters before use (clean filters) were prepared in the way described in the author's previous paper [22].

During the measuring campaigns, basic meteorological parameters such as temperature, pressure, humidity, precipitation, and wind speed were recorded at Ursynów and Zabrze Regional Inspectorate for Environmental Protection stations (https://www.wios.warszawa.pl/, http://powietrze.katowice.wios. gov.pl/stacje/stacja/5).

\subsection{Sample Preparation and Chemical Analysis}

The exposed filters with collected PM1 samples after weighing were divided into four equal pieces. Two of them were used in the study: one part for determination of PM-bound soluble As species, and the second for determination of As total. Concentrations of PM1-bound As speciation forms were measured in PM1 water extracts by using a high-performance liquid chromatography (HPLC) in combination with inductively coupled plasma mass spectrometry (ICP-MS), HPLC-ICP-MS technique. Concentrations of As total were measured in PM1 digests by using ICP-MS technique. Blank samples (empty filters) were prepared simultaneously with PM1 samples in the same way. PM1 water extraction procedure, PM1 mineralization procedure, and operating conditions for the HPLC-ICP-MS and ICP-MS systems are described in detail in the author's previous paper [25].

\subsection{Quality Control and Statistical Analysis}

Quality control of used research methodology was performed using Certified Reference Material of particulate matter (CRM 1648a). Details of the procedure and their results (validation parameters) are presented in the author's previous paper [25].

Statistical analysis of the obtained results were performed by using version 8.0 of Statistica for Windows package, (StatSoft, Tulsa, OK, Poland). Nonparametric Mann-Whitney U test for 
concentrations of the measured analytes $(p<0.05)$ was used to compare seasonal and spatial differences in the concentrations of As total and As soluble species.

\section{Results and Discussion}

Mean concentrations of PM1 and total As in the summer season were comparable in both cities (Table 1). The mean concentration of water-soluble As in the summer season was higher in Zabrze than in Warsaw. In the winter season, mean concentrations of PM1 and water-soluble As were significantly higher $(p<0.05)$ than their concentrations in the summer season both in Zabrze and Warsaw. In the case of total As, higher concentrations in winter were observed only in Zabrze (Table 1). Seasonal differences in mean concentrations of PM1, total As, and water-soluble As were greater in Zabrze than in Warsaw. In earlier research on PM1 in Zabrze, similar seasonal changes in concentrations of PM1 and PM1-bound As were found. With the beginning of the heating season, PM1 concentrations rapidly increase and their mean concentration is three to four times higher than in the non-heating season [23,26]. In Warsaw, the increase in PM1 concentration was not as high as in Zabrze (an increase of only 1.5 times) and the mean concentration of total As in the winter season was even slightly lower than in summer (Table 1). In winter, the increase in water-soluble As concentration in relation to summer was about 3.5- and 3-fold in Zabrze and Warsaw, respectively (Table 1). Considering correlations for $24 \mathrm{~h}$ concentrations of all data (the whole study period), it can be seen that opposite to Warsaw, in Zabrze total As concentrations were correlated with concentrations of both PM1 and water-soluble As (Table 2). This may indicate a considerable share of some PM1 emission source in Zabrze that is a carrier of As and its water-soluble compounds. The correlation of water-soluble As concentrations with PM1 concentration in both cities suggests a common sources of PM1 and water-soluble As. In both Zabrze and Warsaw, two main emission sources of fine PM were identified: first, fuel combustion for energy production and heating purposes, and second, road traffic [27-29]. Clear differences in the intensity and quality of main emissions among the cities, also seasonal, were noticed. Atmospheric air in Warsaw, much more than atmospheric air in Zabrze, is affected by emissions from the dense network of streets with heavy traffic [28]. During the whole measurement period, the intensity of road traffic was much greater there. While road traffic emissions are rather stable throughout the year, emissions from the combustion of raw energy materials are seasonally variable, growing rapidly in autumn and staying high until the end of the heating season (usually the beginning of spring). In Warsaw, coal (hard and/or brawn) and biomass combustion is mainly in power stations and local boiler plants. In winter, individual flats/houses are heated mainly by natural gas combusting and many oil/gas-fired boiler plants are also operating in Warsaw [28]. In Zabrze, hard coal is combusted in power plants throughout the year. In the heating season in many individual flats/houses coal, biomass, and their derivatives (coal dust, wasted furniture, etc.) are burned in household stoves/fireplaces [1]. So far, a higher contribution of road traffic emissions to PM1 concentrations in both seasons in Warsaw compared to Zabrze has been recognized along with a higher contribution of emissions from fossil fuel combustion to PM1 concentrations in Zabrze compared to Warsaw [30]. 
Table 1. Descriptive statistics of $24 \mathrm{~h}$ concentrations of PM1, total As, water-soluble As, and inorganic As species in the air in Zabrze and Warsaw (Poland).

\begin{tabular}{|c|c|c|c|c|c|c|c|c|c|c|}
\hline & \multirow[b]{2}{*}{$n$} & \multicolumn{4}{|c|}{ Zabrze } & \multicolumn{5}{|c|}{ Warsaw } \\
\hline & & Mean & Min. & Max. & SD & $n$ & Mean & Min. & Max. & SD \\
\hline PM1; $\mu \mathrm{g} / \mathrm{m}^{3}$ & 61 & 12.47 * & 6.47 & 20.54 & 3.78 & 60 & $11.07 *$ & 5.67 & 22.62 & 3.27 \\
\hline total As; $\mathrm{ng} / \mathrm{m}^{3}$ & 61 & $2.45 *$ & 0.22 & 8.41 & 1.69 & 60 & $2.59 *$ & - & 7.29 & 1.28 \\
\hline water-soluble As; $\mathrm{ng} / \mathrm{m}^{3}$ & 61 & $* * 0.73 *$ & 0.13 & 1.86 & 0.38 & 60 & $* * 0.25 *$ & - & 0.91 & 0.19 \\
\hline $\mathrm{As}(\mathrm{III}) ; \mathrm{ng} / \mathrm{m}^{3}$ & 61 & $* * 0.17$ & 0.05 & 0.33 & 0.09 & 60 & $* * 0.06$ & 0.03 & 0.14 & 0.02 \\
\hline As $(\mathrm{V}) ; \mathrm{ng} / \mathrm{m}^{3}$ & 61 & $* * 0.61^{*}$ & 0.10 & 1.67 & 0.33 & 60 & $* * 0.27 *$ & 0.06 & 0.95 & 0.17 \\
\hline $\mathrm{PM} 1 ; \mu \mathrm{g} / \mathrm{m}^{3}$ & 56 & $* * 49.25 *$ & 8.30 & 198.50 & 32.07 & 58 & $* * 17.61 *$ & 4.70 & 39.00 & 8.52 \\
\hline total As; $\mathrm{ng} / \mathrm{m}^{3}$ & 56 & $* * 3.36 *$ & 1.16 & 9.99 & 1.54 & 58 & $* * 1.93 *$ & 0.32 & 3.45 & 0.77 \\
\hline water-soluble As; $\mathrm{ng} / \mathrm{m}^{3}$ & 56 & $* * 2.53$ * & 0.26 & 9.99 & 1.58 & 58 & $* * 0.70 *$ & 0.16 & 1.73 & 0.36 \\
\hline $\mathrm{As}(\mathrm{III}) ; \mathrm{ng} / \mathrm{m}^{3}$ & 56 & $* * 0.17$ & 0.02 & 0.96 & 0.16 & 58 & $* * 0.06$ & 0.02 & 0.10 & 0.02 \\
\hline $\mathrm{As}(\mathrm{V}) ; \mathrm{ng} / \mathrm{m}^{3}$ & 56 & $* * 2.41 *$ & 0.22 & 10.03 & 1.58 & 58 & $* * 0.68 *$ & 0.17 & 1.66 & 0.34 \\
\hline
\end{tabular}

$\mathrm{SD}=$ standard deviation; $n=$ number of $24 \mathrm{~h}$ samples; Min. = minimum value; Max. = maximum value. * Element whose summer and winter concentrations in Zabrze or Warsaw are statistically significantly different (according to the Mann-Whitney U test; $p<0.05$ ). ${ }^{* *}$ Summer or winter concentrations in Zabrze and Warsaw are statistically significantly different (according to the Mann-Whitney U test; $p<0.05$ ).

Table 2. Correlations matrix for $24 \mathrm{~h}$ concentrations of PM1, total As, water-soluble As, As(III) and As(V) and correlations between 24 h concentrations of PM1, total As, water-soluble As, As(III), As(V), and $24 \mathrm{~h}$ averaged meteorological factors in Zabrze and Warsaw.

\begin{tabular}{|c|c|c|c|c|c|c|c|c|c|c|}
\hline & PM1 & Total As & Water-Soluble As & As(III) & $\operatorname{As}(\mathrm{V})$ & Temp. & Hum. & Prec. & Wind s. & Pres. \\
\hline \multicolumn{11}{|c|}{ Zabrze } \\
\hline PM1 & 1.00 & & - & - & - & -0.61 & 0.16 & -0.27 & -0.10 & 0.12 \\
\hline total As & * 0.59 & 1.00 & - & - & - & -0.29 & -0.01 & -0.27 & -0.07 & 0.08 \\
\hline water-soluble As & 0.88 & 0.62 & 1.00 & - & - & -0.60 & 0.16 & -0.23 & -0.06 & 0.08 \\
\hline $\mathrm{As}(\mathrm{III})$ & 0.20 & 0.30 & 0.37 & 1.00 & - & 0.10 & -0.05 & -0.17 & -0.18 & 0.00 \\
\hline $\mathrm{As}(\mathrm{V})$ & 0.89 & 0.61 & 0.99 & 0.30 & 1.00 & -0.61 & 0.15 & -0.23 & -0.05 & 0.07 \\
\hline \multicolumn{11}{|c|}{ Warsaw } \\
\hline PM1 & 1.00 & - & - & - & - & -0.39 & 0.16 & -0.24 & -0.26 & 0.10 \\
\hline total As & -0.08 & 1.00 & - & - & - & 0.27 & 0.05 & 0.04 & -0.24 & -0.15 \\
\hline water-soluble As & 0.77 & -0.05 & 1.00 & - & - & -0.56 & 0.23 & -0.24 & 0.02 & 0.07 \\
\hline As(III) & 0.34 & 0.19 & 0.38 & 1.00 & - & 0.09 & -0.03 & -0.08 & -0.26 & -0.01 \\
\hline $\mathrm{As}(\mathrm{V})$ & 0.77 & -0.03 & 0.99 & 0.38 & 1.00 & -0.56 & 0.24 & -0.23 & 0.02 & 0.09 \\
\hline
\end{tabular}

${ }^{*}$ statistically significant correlations $(p<0.05)$ with values of linear correlation coefficient $(\mathrm{r})$ greater than 0.5 are marked in red. Temp.-Air temperature; Hum. - Air relative humidity;

Prec.-Precipitation; Wind s.-Wind speed; Pres.-Atmospheric pressure. 
The differences in the PM1 emission profile in the cities were reflected in As characteristics in the following way: in the summer, the mean As total concentration was comparable in both cities, but the mass share of its inorganic species in total As mass was 2.5-times higher in PM1 from Zabrze (47\%) than from Warsaw (18\%). During the winter, the mean total As concentration was 1.7-times higher in Zabrze and the mass share of its inorganic species in total As mass was 3.6-times higher in PM1 from Zabrze (75\%) than from Warsaw (44\%) (Tables 1 and 3). Similar mass shares of water-soluble As in the total As mass were reported for PM2.5 collected near lignite power plants (49\%) [13], in a tunnel of a traffic road (50\%) [9], and for PM2.5 from long-range transport of industrial air pollution (68\%) [10]. A higher share was reported for PM1 collected near coking power plants (98\%) [15]. 
Table 3. Percentage of PM1-bound inorganic As species (As(III) and As(V)) in PM1-bound total As in Zabrze and Warsaw (Poland).

\begin{tabular}{|c|c|c|c|c|c|c|c|c|c|c|}
\hline & \multicolumn{5}{|c|}{ Zabrze } & \multicolumn{5}{|c|}{ Warsaw } \\
\hline & $n$ & Mean & Min. & Max. & SD & $n$ & Mean & Min. & Max. & SD \\
\hline \multicolumn{11}{|c|}{ Summer season/non-heating } \\
\hline As(III) \% & 61 & 10.98 & 1.39 & 39.93 & 8.98 & 60 & 3.51 & 0.78 & 33.33 & 4.83 \\
\hline $\operatorname{As}(\mathrm{V}) \%$ & 61 & 36.26 & 3.30 & 86.46 & 26.20 & 60 & 14.60 & 1.41 & 89.61 & 17.02 \\
\hline $\mathrm{As}(\mathrm{III})+\mathrm{As}(\mathrm{V}) \%$ & 61 & 47.24 & 4.96 & 99.98 & 33.65 & 60 & 18.11 & 2.47 & 100.00 & 20.67 \\
\hline $\mathrm{As}(\mathrm{V}) / \mathrm{As}(\mathrm{III})$ & 61 & 3.77 & 1.33 & 9.33 & 1.76 & 60 & 4.34 & 1.33 & 10.00 & 2.43 \\
\hline \multicolumn{11}{|c|}{ Winter season/heating } \\
\hline As(III) \% & 56 & 4.94 & 0.76 & 23.73 & 4.15 & 58 & 3.70 & 1.04 & 10.90 & 2.14 \\
\hline $\operatorname{As}(\mathrm{V}) \%$ & 56 & 70.52 & 7.94 & 97.36 & 24.54 & 58 & 40.12 & 12.43 & 96.40 & 23.90 \\
\hline $\mathrm{As}(\mathrm{III})+\mathrm{As}(\mathrm{V}) \%$ & 56 & 75.46 & 8.69 & 100.94 & 25.18 & 58 & 43.82 & 13.47 & 100.01 & 25.47 \\
\hline $\mathrm{As}(\mathrm{V}) / \mathrm{As}(\mathrm{III})$ & 56 & 18.52 & 1.43 & 42.50 & 8.63 & 58 & 11.67 & 4.00 & 26.67 & 5.11 \\
\hline
\end{tabular}

$\mathrm{SD}=$ standard deviation; $n=$ number of 24 -h samples; Min. = minimum value; Max. = maximum value. 
As $(\mathrm{V})$ was the dominant soluble form of As in PM1 in both cities during the study period. In both seasons, $24 \mathrm{~h}$ concentrations of PM1-bound inorganic As $(\mathrm{V})$ were higher in Zabrze than in Warsaw (Figures 2 and 3). Mean seasonal concentrations of $A s(V)$ ranged from $0.27 \mathrm{ng} / \mathrm{m}^{3}$ in the summer season in Warsaw to $2.41 \mathrm{ng} / \mathrm{m}^{3}$ in the winter season in Zabrze (Table 1). Both the mean seasonal concentration of $\mathrm{As}(\mathrm{V})$ in PM1 and its mass percentage in total As were higher in Zabrze than in Warsaw: about 2 and 3.5 times, respectively, in the summer season and 2.5 and 1.8 times, respectively, in the winter season (Tables 1 and 3). Both in Zabrze and Warsaw, mean concentrations of $\mathrm{As}(\mathrm{V})$ were higher in winter (heating period) than in summer (non-heating period), their seasonal variation was much greater in Zabrze (Table 1).

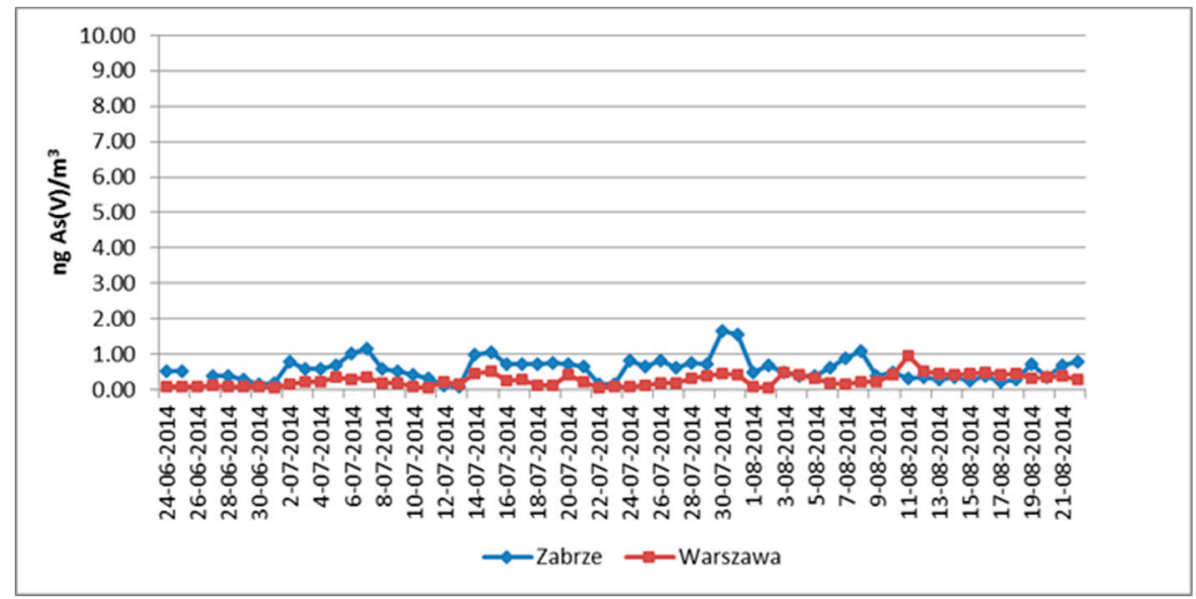

Figure 2. Twenty-four hour concentrations of PM1-bound water-soluble As(V) $\left(\mathrm{ng} / \mathrm{m}^{3}\right)$ in Zabrze and Warsaw in the summer season.

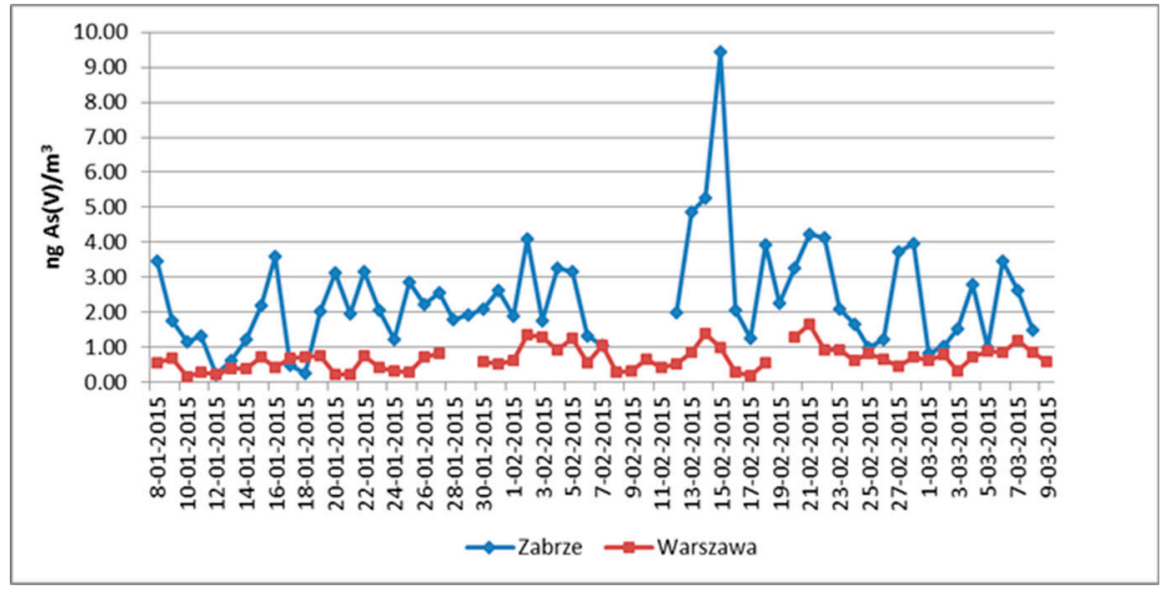

Figure 3. Twenty-four hour concentrations of PM1-bound water-soluble $\mathrm{As}(\mathrm{V})\left(\mathrm{ng} / \mathrm{m}^{3}\right)$ in Zabrze and Warsaw in the winter season.

In the winter season in Warsaw, the mean seasonal concentration of $\mathrm{As}(\mathrm{V})$ was about 2.5 times higher than in summer, and $\mathrm{As}(\mathrm{V})$ constituted $40 \%$ mass of total As (Tables 1 and 3). In Zabrze, seasonal differences in concentrations of $\mathrm{As}(\mathrm{V})$ were much greater than in Warsaw. In the winter season, the mean seasonal concentration of soluble $\mathrm{As}(\mathrm{V})$ was about four times higher than in summer, and $\mathrm{As}(\mathrm{V})$ constituted $70.5 \%$ mass of total As (Tables 1 and 3 ).

In contrary to concentrations of $\mathrm{As}(\mathrm{V})$, concentrations of $\mathrm{As}(\mathrm{III})$ were not clearly seasonally variable (summer and winter concentrations in Zabrze or Warsaw were not statistically significantly different; $p<0.05$ ) (Table 1, Figures 4 and 5). In both summer and winter, mean concentrations of As(III) were almost three times higher in Zabrze $\left(0.17 \mathrm{ng} / \mathrm{m}^{3}\right)$ than in Warsaw $\left(0.06 \mathrm{ng} / \mathrm{m}^{3}\right)$ (Table 1). In 
turn, As(III) mass percentage in total As was comparable in summer and winter in Warsaw, and it was two times higher in summer than in winter in Zabrze (Table 3).

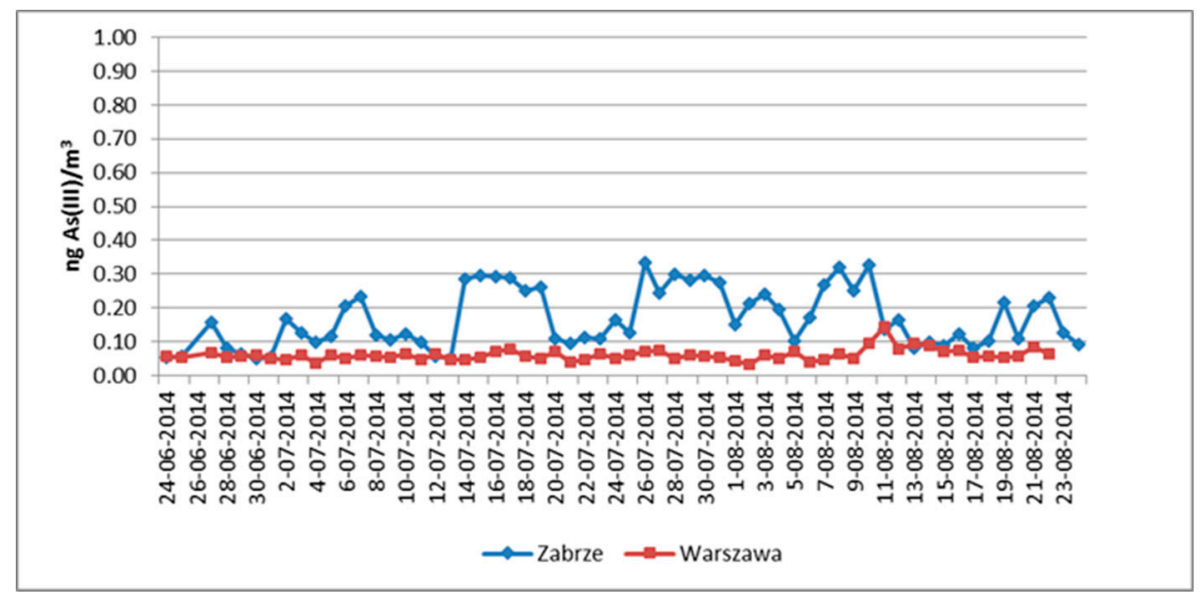

Figure 4. Twenty-four hour concentrations of PM1-bound water-soluble As(III) $\left(\mathrm{ng} / \mathrm{m}^{3}\right)$ in Zabrze and Warsaw in the summer season.

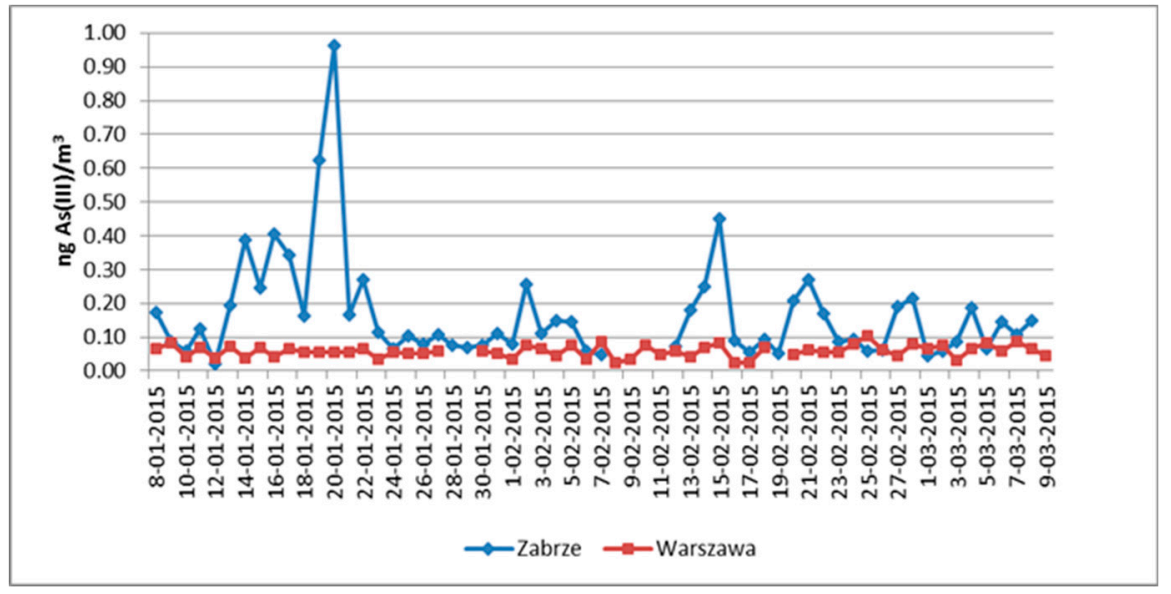

Figure 5. Twenty-four hour concentrations of PM1-bound water-soluble As(III) $\left(\mathrm{ng} / \mathrm{m}^{3}\right)$ in Zabrze and Warsaw in the winter season.

It is clear that the origin of PM is a main factor shaping the chemical properties of all elements in PM, such as their solubility; As(V) and As(III) share in total As can also be determined by sources of PM [10]. In our previous work, we suggest that in Zabrze PM1-bound As come mainly from fossil fuels combustion. What is more, As compounds from this source influence not only amounts of soluble $\mathrm{As}(\mathrm{V})$ in the ambient air, but also its share in total PM1-bound As [25].

The analysis of the relationship among PM1, total As, water-soluble As, As(V), and As(III) in Zabrze (Table 2) shows a significant correlation between As(V) and PM1 $(r=0.89)$. There were weaker but also significant correlations between $\mathrm{As}(\mathrm{V})$ and total As ( $\mathrm{r}=0.61)$, and between PM1 and total As $(r=0.59)$ (Table 2). Among meteorological factors, that is, temperature, air pressure, humidity, precipitation, and wind speed, a correlation was observed only with temperature (a negative one) $(\mathrm{r}=-0.60)$. The results may suggest an association of $\mathrm{As}(\mathrm{V})$ ambient concentrations with the activity of the emission source of PM1 and its components (e.g., As). It was proved through the above analysis that local municipal emission (i.e., coal and biomass combustion in local stoves) was responsible for high winter As(V) concentrations in Zabrze. 
A different situation was observed in Warsaw. There was no correlation between water-soluble As(V) and total As or between PM1 and total As (Table 2). Some source(s) of PM1 were likely source(s) of $\mathrm{As}(\mathrm{V})$ that were mainly water insoluble or were in organic forms (second emissions from some surfaces, e.g., soil, roads). As $(\mathrm{V})$ was correlated with PM1 ( $\mathrm{r}=0.77)$ and with ambient air temperature $(\mathrm{r}=-0.56)$ (Table 2). It seems that in Warsaw, the sources of PM1 could also be direct sources of water-soluble $\mathrm{As}(\mathrm{V})$. Its relation to ambient temperature, this suggests there were emissions from energy production. Therefore, it seems that submicron particles emitted by power and heat production sectors are probably a better carrier of As total and source of water-soluble As(V) than submicron particles from road emissions (exhaust).

For As(III), no correlations with PM1, total As, water-soluble As, or meteorological factors were noticed in both cities (Tables 1 and 2). As(III) ambient concentrations were probably not directly connected with main PM1 and total As emission sources. It seems that soluble As(III) emission sources was variable and none of them clearly dominated during the measuring campaign in both cities.

Figures 6 and 7 show a distribution of the concentrations of PM1, As(III), and As(V) in Zabrze and Warsaw with reference to eight wind directions. The highest concentrations of PM1 and As(V) in Zabrze were noted on days when the air masses came from the S, N and NE (Figure 6), which are the directions of emissions from dispersed, local sources, such as:
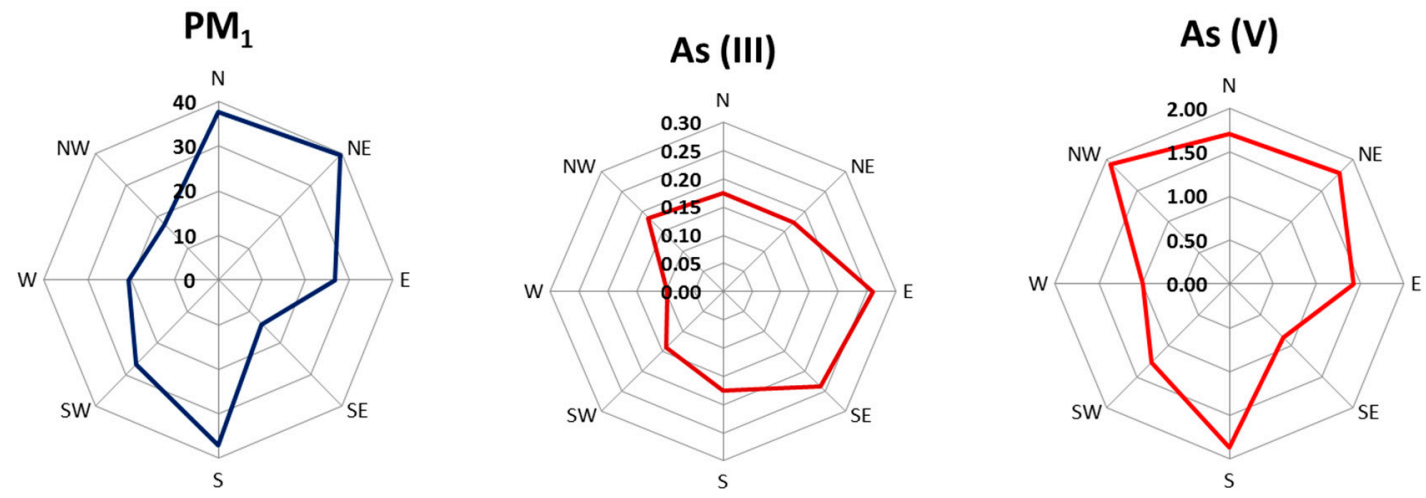

Figure 6. Distribution of the concentration of PM1 and selected components of PM1 $\left(\mu \mathrm{g} \mathrm{m}^{-3}\right)$ in Zabrze with reference to eight wind directions.
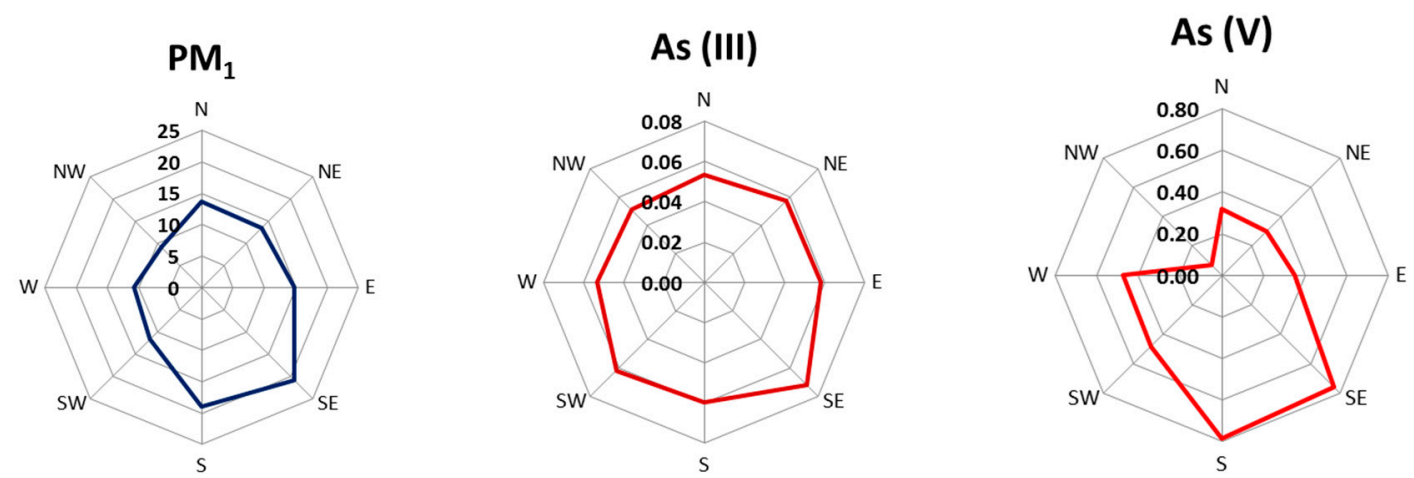

Figure 7. Distribution of the concentration of PM1 and selected components of PM1 $\left(\mu \mathrm{g} \mathrm{m}^{-3}\right)$ in Warsaw with reference to eight wind directions.

in the $S$ direction-small local furnaces/stoves/boilers in houses or flats (coal, gas, or electricity-powered),

in the $\mathrm{N}$ direction-the nearest trunk road (approx. $500 \mathrm{~m}$ ),

in the NE direction-local roads with high traffic during rush hour and, further, Huta Zabrze steelworks. 
$\mathrm{As}(\mathrm{V})$ concentrations were also high when air masses came from the NW, where a trunk road (approx. $800 \mathrm{~m}$ ), a housing estate (block of flats), and allotments are situated.

The highest concentrations of PM1 and soluble As(V) in Warsaw coincided with the S and SE wind directions (Figure 7). Small local houses with boilers and furnaces and also significant numbers of high traffic streets are located in the SE and S directions from the measurement site (the nearest ones are about $500 \mathrm{~m}$ in the SE and $1000 \mathrm{~m}$ in the S) [22]. There are the Silesia region further to the south from measurement site. It is supposed that air contaminants from the Silesia reaches the central part of the country [28]. For example, concentrations of PM2.5-bound As were much higher than average when wind speed was higher and blew mostly from the direction of the Silesia region [28].

The highest concentrations of As(III) in Zabrze were observed when air masses were flowing from the $\mathrm{E}$ and SE directions, where blocks of flats and residential houses (E) as well as Zabrze city center, with residential and commercial housing (SE) are located (Figure 6). In Warsaw, As(III) concentrations were rather evenly distributed with an indication of the SE direction where residential buildings with individual stoves and oil and gas-fired boilers prevail (Figure 7).

Considering the above, there is a probability that $\mathrm{As}(\mathrm{V})$ originating from fuels combustion was more likely to become water-soluble than that coming from traffic emissions and other minor sources. However, other factors except PM origin that affect As species solubility should also be taken into account. The composition of the PM matrix and the strength of As binding to the matrix can also play a significant role in its susceptibility to leaching in water. Available data on the chemical composition of a surface layer of submicron particles (only for Zabrze) showed that elemental carbon represented about $78-80 \%$ (atomic mass) of all determined elements [31]. Metals condensed or adsorbed on the surface of a PM component (e.g., elemental carbon) tend to be more easily released to the environment compared to metals bound onto crustal matter [32].

The differences in seasonal ambient concentrations of water-soluble As(III) and As(V) in Zabrze and Warsaw could also be connected with different concentrations of some components of PM1 that could affect the $\mathrm{pH}$ of its water extracts. Among water-soluble components, $\mathrm{SO}_{4}{ }^{2-}$ and $\mathrm{Cl}^{-}$are the most able to acidify a solution of extracted PM. In both cities and both seasons, $\mathrm{SO}_{4}{ }^{2-}$ was one of the major components, but the greatest seasonal increase in concentration was noted for $\mathrm{Cl}^{-}$. Earlier research suggested an acidic $\mathrm{pH}$ for PM1 from Zabrze [23,26]. The ambient PM1-bound concentrations of carbon, $\mathrm{SO}_{4}{ }^{2-}$ and $\mathrm{Cl}^{-}$were higher in winter in both cities, and higher in Zabrze than in Warsaw for both seasons [30]. The higher mean concentrations of PM1-bound soluble As(V) and As(III) in winter in both cities and in Zabrze for both seasons, was probably caused by the physicochemical conditions during leaching.

Cloud processing was found to affect PM-bound elements solubility and aerosol elements [10]. Enhanced solubility of some trace elements corresponding to increased concentrations of sulfate after the occurrence of cloud events was reported by $\mathrm{Li}[10]$.

\section{Conclusions}

A long measurement campaign (120 days) conducted in two Polish urban background sites (Zabrze and Warsaw) let to provide a rich database of both total PM1-bound As as well as its inorganic species bound in easily water-soluble compounds. The obtained results indicated that:

The mean seasonal ambient concentrations of water-soluble $\mathrm{As}(\mathrm{V})$ and its variations were much higher in Zabrze than in Warsaw. It can be stated that results of a chemical speciation of As in PM1 indicated more toxicity of PM1 in Zabrze.

The mean mass shares of water-soluble $\mathrm{As}(\mathrm{V})$ in total As in the winter were $44 \%$ in Warsaw and $75 \%$ in Zabrze. In the summer, they were $18 \%$ and $48 \%$, respectively. It was connected with higher emissions of carbon compounds sulfate and nitrate to the atmosphere from fuel combustion in winter in both cities. 
The main source of PM1-bound As(V) leachable in water was fossil fuel combustion, more intensive in Zabrze (municipal emission) than in Warsaw. The minor sources were road emission (exhaust) and secondary emission from surfaces such as soil and roads (resuspension).

The mean mass shares of water-soluble As(III) in total As were higher in summer (11\%) than in winter (5\%) in Zabrze, and comparable in both seasons in Warsaw (3.5\% and 3.7\%, respectively).

Ambient concentrations of water-soluble As(III) and its contents of total As and in PM1 were not preferentially shaped by an exact emission source in both cities.

The work refers to very rarely undertaken research on water-soluble arsenic species in submicron particulate matter (PM1). The intention of authors was to determine most soluble chemical species of As that are considered potentially bioavailable. In this context, these results can be used to assess the exposure to inorganic compounds of $\mathrm{As}(\mathrm{III})$ and $\mathrm{As}(\mathrm{V})$ for populations in the study area and inspire to conduct such studies in other areas.

Author Contributions: Conceptualization, W.R.-K., K.N.; Data curation, P.R.-K., K.N.; Investigation, W.R.-K., K.N., P.R.-K., G.M.; Methodology, W.R.-K., K.N., P.R.-K., G.M.; Supervision, W.R.-K., G.M.; Writing-original draft, K.N.; Writing - review \& editing, W.R.-K. All authors have read and agreed to the published version of the manuscript.

Funding: The work was carried out in the frame of two research projects (No. 2016/23/N/ST10/03032 and No. 2012/07/D/ST10/02895) financed by the National Science Center and implemented at the Institute of Environmental Engineering of the Polish Academy of Sciences in Zabrze. Chemical analyses were carried out in the frame of the project No. 2016/23/N/ST10/03032 and archival PM1 samples taken from the project No. 2012/07/D/ST10/02895.

Conflicts of Interest: The authors declare no conflict of interest.

\section{References}

1. Rogula-Kozłowska, W.; Majewski, G.; Czechowski, P.O. The size distribution and origin of elements bound to ambient particles: A case study of a Polish urban area. Environ. Monit. Assess. 2015, 187, 240. [CrossRef] [PubMed]

2. Rivellini, L.H.; Chiapello, I.; Tison, E.; Fourmentin, M.; Feron, A.; Diallo, A.; N’Diaye, T.; Goloub, P.; Canonaco, F.; Prevot, A.; et al. Chemical characterization and source apportionment of submicron aerosols measured in Senegal during the 2015 SHADOW campaign. Atmos. Chem. Phys. 2017, 17, 10291-10314. [CrossRef]

3. IARC. Arsenic and Arsenic Compounds. In IARC Monographs on the Evaluation of Carcinogenic Risk to Humans; IARC Press: Lyon, France, 2012; Volume 23, 100C.

4. Matschullat, J. Arsenic in the geosphere-a review. Sci. Total Environ. 2000, 249, 297-312. [CrossRef]

5. Chen, B.; Stein, A.F.; Maldonado, P.G.; Sanchez de la Campa, A.M.; Gonzalez-Castanedo, Y.; Castell, N.; de la Rosa, J.D. Size distribution and concentrations of heavy metals in atmospheric aerosols originating from industrial emissions as predicted by the HYSPLIT model. Atmos. Environ. 2013, 71, 234-244. [CrossRef]

6. WHO. Air Quality Guidelines for Europe, WHO Regional Publications, 2nd ed.; Regional Office for Europe: Copenhagen, Denmark, 2001.

7. Pulles, T.; Denier van der Gon, H.; Appelman, W.; Verheul, M. Emission factors for heavy metals from diesel and petrol used in European vehicles. Atmos. Environ. 2012, 61, 641-651. [CrossRef]

8. Onat, B.; Sahin, U.A.; Akyuz, T. Elemental characterization of PM2.5 and PM1 in dense traffic area in Istanbul, Turkey. Atmos. Pollut. Res. 2013, 4, 101-105. [CrossRef]

9. Slejkovec, Z.; Salma, I.; van Elteren, J.T.; Zemplén-Papp, E. Speciation of arsenic in coarse and fine urban aerosols using sequential extraction combined with liquid chromatography and atomic fluorescence detection. Fresenius J. Anal. Chem. 2000, 366, 830-834. [CrossRef]

10. Li, T.; Wang, Y.; Li, W.J.; Chen, J.M.; Wang, T.; Wang, W.X. Concentrations and solubility of trace elements in fine particles at a mountain site, southern China: Regional sources and cloud processing. Atmos. Chem. Phys. 2015, 15, 8987-9002. [CrossRef]

11. Sarti, E.; Pasti, L.; Rossi, M.; Ascanelli, M.; Pagnoni, A.; Trombini, M.; Remelli, M. The composition of PM1 and PM2.5 samples, metals and their water soluble fractions in the Bologna area (Italy). Atmos. Pollut. Res. 2015, 6, 708-718. [CrossRef] 
12. Qureshi, S.; Dutkiewicz, V.A.; Swami, K.; Yang, K.X.; Husain, L.; Schwab, J.J.; Demerjian, K.L. Elemental composition of PM2.5 aerosols in Queens, New York: Solubility and temporal trends. Atmos. Environ. 2006, 40, 238-251. [CrossRef]

13. Manousakas, M.; Papaefthymiou, H.; Eleftheriadis, K.; Katsanou, K. Determination of water-soluble and insoluble elements in PM2.5 by ICP-MS. Sci. Total Environ. 2014, 493, 694-700. [CrossRef]

14. Zajusz-Zubek, E.; Kaczmarek, K.; Mainka, A. Trace Elements Speciation of Submicron Particulate Matter (PM1) Collected in the Surroundings of Power Plants. Int. J. Environ. Res. Public Health 2015, 12, 13085-13103. [CrossRef]

15. Zajusz-Zubek, E.; Radko, T.; Mainka, A. Fractionation of trace elements and human health risk of submicron particulate matter (PM1) collected in the surroundings of coking plants. Environ. Monit. Assess. 2017, 189, 389. [CrossRef]

16. Galon-Negru, A.G.; Olariu, R.I.; Arsene, C. Size-resolved measurements of PM2.5 water-soluble elements in Iasi, north-eastern Romania: Seasonality, source apportionment and potential implications for human health. Sci. Total Environ. 2018, 695, 133839. [CrossRef]

17. Du, L.; Wang, Y.; Wu, Z.; Hou, C.; Mao, H.; Li, T.; Nie, X. PM 2.5 -Bound Toxic Elements in an Urban City in East China: Concentrations, Sources, and Health Risks. Int. J. Environ. Res. Public Health. 2019, 16, 164. [CrossRef]

18. Niedzielski, P.; Siepak, M.; Siepak, J. Występowanie i zawartości arsenu, antymonu i selenu w wodach i innych elementach środowiska naturalnego. Rocznik Ochrona Srodowiska 2000, 2, 317-340. (In Polish)

19. Lewis, A. Speciated arsenic in air: Measurement methodology and risk assessment considerations. J. Air Waste Manag. Assoc. 2012, 62, 2-17. [CrossRef]

20. Nocon, K.; Rogula-Kozłowska, W.; Widziewicz, K. Research on chromium and arsenic speciation in atmospheric particulate matter: Short review. E3S Web Conf. 2018, 28. [CrossRef]

21. Rogula-Kozłowska, W.; Klejnowski, K.; Rogula-Kopiec, P.; Ośródka, L.; Krajny, E.; Błaszczak, B.; Mathews, B. Spatial and seasonal variability of the mass concentration and chemical composition of $\mathrm{PM}_{2.5}$ in Poland. Air Qual. Atmos. Health 2014, 7, 41-58. [CrossRef]

22. Majewski, G.; Rogula-Kozłowska, W.; Rozbicka, K.; Rogula-Kopiec, P.; Mathews, B.; Brandyk, A. Concentration, Chemical Composition and Origin of PM1: Results from the First Long-term Measurement Campaign in Warsaw (Poland). Aerosol Air Qual. Res. 2018, 18, 636-654. [CrossRef]

23. Rogula-Kozłowska, W. Size-segregated urban particulate matter: Mass closure, chemical composition, and primary and secondary matter content. Air Qual. Atmos. Health 2016, 9, 533-550. [CrossRef] [PubMed]

24. EC. Directive 2008/50/EC of the European Parliament and of the Council of 21 May 2008 on Ambient Air Quality and Cleaner Air for Europe. Available online: https://eur-lex.europa.eu/legal-content/EN/TXT/?qid= 1579695287064\&uri=CELEX:32008L0050 (accessed on 22 January 2020).

25. Nocoń, K.; Rogula-Kozłowska, W. Speciation of arsenic: A case study of PM1 in Zabrze. SN Appl. Sci. 2019, 1, 450. [CrossRef]

26. Rogula-Kozłowska, W.; Klejnowski, K. Submicrometer Aerosol in Rural and Urban Backgrounds in Southern Poland: Primary and Secondary Components of PM1. Bull. Environ. Contam. Toxicol. 2013, 90, 103. [CrossRef] [PubMed]

27. Rogula-Kozlowska, W.; Błaszczak, B.; Klejnowski, K. Concentrations of PM2.5, PM2.5-10 and PM- related elements at two heights in an urban background area in Zabrze (Poland). Arch. Environ. Prot. 2011, 37, 31-49.

28. Majewski, G.; Rogula-Kozłowska, W. The elemental composition and origin of fine ambient particles in the largest Polish conurbation: First result from the short-term winter campaign. Theor. Appl. Climatol. 2016, 125, 79. [CrossRef]

29. Rogula-Kozłowska, W.; Błaszczak, B.; Szopa, S.; Klejnowski, K.; Sówka, I.; Zwoździak, A.; Jabłońska, M.; Mathews, B. PM2.5 in the central part of Upper Silesia, Poland: Concentrations, elemental composition, and mobility of components. Environ. Monit. Assess. 2013, 185, 581-601. [CrossRef]

30. Rogula-Kozłowska, W.; Majewski, G.; Rogula-Kopiec, P.; Mathews, B.A. Mass concentration and chemical composition of submicron particulate matter (PM1) in the Polish urban areas. IOP Conf. Ser. Earth Environ. Sci. 2019, 214, 012092. [CrossRef] 
31. Klejnowski, K.; Pastuszka, J.S.; Rogula-Kozłowska, W.; Talik, E.; Krasa, A. Mass size distribution and chemical composition of the surface layer of summer and winter airborne particles in Zabrze, Poland. Bull. Environ. Contam. Toxicol. 2012, 88, 255-259. [CrossRef]

32. Heal, M.R.; Hibbs, L.R.; Agius, R.M.; Beverland, I.J. Total and water-soluble trace metal content of urban background PM10, PM2.5 and black smoke in Edinburgh, UK. Atmos. Environ. 2005, 39, 1417-1430. [CrossRef]

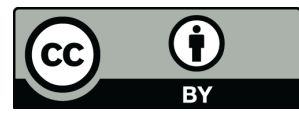

(C) 2020 by the authors. Licensee MDPI, Basel, Switzerland. This article is an open access article distributed under the terms and conditions of the Creative Commons Attribution (CC BY) license (http://creativecommons.org/licenses/by/4.0/). 